Volume 7, No. 1, 2021

ISSN (print) : 2442-3217

ISSN (online) : 2716-3806

Homepage : http://journal.iaimsinjai.ac.id/indeks.php/mimbar

\title{
Kontribusi dan Dinamika Kehidupan Muslim di Republik Yaman
}

\section{(Kajian Sejarah Dakwah)}

\author{
Faridah, ${ }^{1}$, Muhammad Yusuf ${ }^{2}$, R. Firdaus Wahyudi ${ }^{3}$ \\ ${ }^{1}$ Institut Agama Islam Muhammadiyah Sinjai, Sinjai \\ Email; andifaridah81@gmail.com \\ ${ }^{2}$ Sekolah Tinggi Agama Islam Darud Dakwah Wal Irsyad Makassar, Makassar \\ Email: yusufburhan8588@gmail.com \\ ${ }^{3}$ Institut Agama Islam Muhammadiyah Sinjai, Sinjai \\ Email: cheyudi@gmail.com
}

\begin{abstract}
Abstrak:
Penelitian ini mengungkap tentang Kontribusi dan Dinamika Kehidupan Muslim di Republik Yaman (Kajian Sejarah Dakwah), ada tiga aspek yang menjadi bahan analisis dalam hal ini yakni sejarah kedatangan Islam di Republik Yaman, terjadinya konflik di Republik Yaman dan kontribusi peradaban Islam Republik Yaman bagi dunia. Kedatangan Islam di Yaman terjadi pada masa pemerintahan Gubernur Persia Badhan. Islam masuk ke Yaman bermula pada tahun $630 \mathrm{M}$. Nabi Muhammad SAW mengutus Ali bin Abi Thalib RA saudara sepupu sekaligus menantunya ke Sana'a dan sekitarnya untuk menyampaikan sviar Islam. Namun, kehidupan di Republik Yaman diwarnai oleh konflik yang disebabkan oleh berbagai faktor dan kepentingan termasuk ekonomi, sosial, agama dan politik. Meskipun demikian Republik Yaman memberikan kontribusi vang sangat besar bagi peradaban dunia yakni mentransfer banyak pengetahuan, berpartisipasi dalam mendirikan kota dan membangun benteng, serta pembangunan istana dan keterampilan lainnya. Di samping itu penduduk Republik Yaman terlibat aktif di kancah kemiliteran pada masa kekhalifahan, mereka turut berpartisipasi dalam ekspedisi perluasan wilayah Islam yang berakhir sukses.
\end{abstract}

Kata Kunci: Kontribusi, Republik Yaman, Peradaban Islam, Sejarah dakwah 


\section{BAB I PENDAHULUAN}

\section{A. Latar Belakang Masalah}

Sejarah merupakan rangkaian dari kisah perjalanan hidup umat manusia dari masa ke masa. Kisah perjalanan tersebut banyak direkam dalam berbagai bentuk untuk dipelajari dan dianalisis. Perekaman sejarah dalam bentuk tulisan atau sejenisnya menjadi suatu bukti adanya kehidupan dan perkembangannya di dunia.

Sejarah memiliki arti dan nilai yang sangat besar dalam kehidupan umat manusia. Dalam kehidupannya, manusia telah menciptkan sejarah sendiri dan sejarah pun telah membentuk manusia. Memanfaatkan sejarah sebagai suatu bahan kajian dan analisis berdampak pada perkembangan peradaban manusia. Sejarah diyakini dapat kembali berulang dengan peristiwa lama dan sama. Dalam mengkajinya, sejarah memiliki arti dan memberi arti kepada manusia bahwa dunia bagaikan berputar di sekeliling diri manusia sendiri kemudian ditulis agar menjadi gambaran atau sebagai tuntunan atau menjadi suatu bentuk laporan, adanya berbagai hal seperti teguran yang tegas, keras dan lembut untuk umat manusia yang bersedia membacanya, suatu gambaran yang memberikan makna agar manusia menghindari mengulang melakukan suatu hal yang merugikan dan mengecewakan. Dalam kehidupan umat 




\section{MIMBAR}

Jurmal Media Intelektual Muslim dan Bimbingan Rohani

Volume 7, No. 1, 2021

ISSN (print) : 2442-3217

ISSN (online) : 2716-3806

Homepage : http://journal.iaimsinjai.ac.id/indeks.php/mimbar

Islam, sejarah memegang peran yang sangat penting, sejarah dalam hal ini berfungsi sebagai petunjuk dan penuntun. ${ }^{1}$

Pentingnya mempelajari sejarah menghadirkan suatu bentuk keilmuan tersendiri yang menjadikan sejarah tersebut dapat dikaji secara komprehensip. Namun dalam mempelajari sejarah diperlukan berbagai metodologi termasuk dalam pembagian pembelajaran berdasarkan babakan yang termuat dalam suatu perode yang lazim disebut periodisasi. ${ }^{2}$

Adapun Periodisasi sejarah Islam dapat ditinjau dan dikaji berdasarkan tiga periode yaitu periode klasik $( \pm 600-1258)$, periode pertengahan (dari jatuhnya Baghdad sampai kepenghujung abad ke-17) dan periode modern yaitu mulai abad ke18. Adanya sIstem periodisasi tersebut memudahkan dilakukannya kajian sejarah, dengan kata lain hal ini diharapkan dapat mengurangi kesulitan-kesulitan akibat panjangnya perjalanan sejarah yang akan dikaji dan dianalisis.

Berdasarkan letak wilayah, Republik Yaman merupakan sebuah Negara di Jazirah Arab yakni di Asia Barat Daya bagian dari Timur Tengah. Republik Yaman berbatasan dengan laut Arab di sebelah Selatan, teluk Aden dan laut merah di sebalah barat, Oman di sebalah timur dan Arab Saudi di sebelah utara. Menurut penelusuran sejarah diketahui bahwa orang-orang keturunan Arab di Indinesia berasal dari Negara Yaman. Pendudk Yaman diperkirakan berjumlah 23 juta jiwa dengan luas wilayah $530.000 \mathrm{~km}^{2}$, serta wilayah yang terdiri dari 200 pulau. Yaman adalah satu-satunya Negara yang berbentuk republic di jazirah Arab. ${ }^{3}$

Hal lain yang dikenal tentang Republik Yaman adalah bahwa Republik Yaman merupakan negeri tempat menuntut ilmu agama, tepatnya di kota Hadramaut. Dari kota itu, dakwah Islam disiarkan ke berbagai negara tidak terkecuali Indonesia. ${ }^{4}$

${ }^{1}$ Samsul Munir Amin, Sejarah Peradaban Islam(Cet. II; Jakarta: Sinar Grafika Offset, 2010), h. 3

${ }^{2}$ Nourouzzaman Shiddiqie, Pengantar Sejarah Muslim (Yogyakarta: Nur Cahaya, 1983), h.65. ${ }^{3}$ http://www.geografi.org/2017/04, diakses Jum'at 02 April 2021.

4 Habib Umar bin Al Hafizh Jelaskan Yaman Mercusuar Ilmu, https://republika.co.id/tag/islam-di-yaman (Monday, 11 May 2020 18:13 WIB) 




\section{MIMBAR}

Jurmal Media Intelektual Muslim dan Bimbingan Rohani

Volume 7, No. 1, 2021

ISSN (print) : 2442-3217

ISSN (online) : 2716-3806

Homepage : http://journal.iaimsinjai.ac.id/indeks.php/mimbar

Berdasarkan pembahasan tersebut dan keberadaan Republik Yaman sebagai salah satu negara dalam bagian jazirah arab menjadikannya tidak luput dalam kajian sejarah Islam. Islam yang mulai muncul di Arab tentunya berdampak dan memiliki kisah tersendiri di wilayah sekitar daerah kelahirannya. Hal inilah menginspirasi penelusuran dan pengkajian Islam di Republik Yaman serta konflik yang terjadi di sana, kontribusinya terhadap peradaban Islam ditinjau dari sejarah dakwah.

\section{B. Rumusan Masalah}

Berdasarkan latar belakang masalah di atas, yang menjadi pokok masalah dalam makalah Sejarah Konflik Di Yaman ini dirumuskan ke dalam beberapa sub masalah sebagai berikut:

1. Bagaimana sejarah kedatangan Islam di Republik Yaman?

2. Bagaimana terjadinya konflik di Republik Yaman?

3. Bagaimana kontribusi peradaban Islam Republik Yaman bagi dunia?

\section{Tujuan Penulisan}

Adapun tujuan penulis meneliti dan menelusuri tema ini adalah untuk mengetahui, menganalisis dan mendeskripsikan beberap hal pokok sebagai berikut:

1. Sejarah kedatangan Islam di Republik Yaman

2. Terjadinya konflik di Republik Yaman

3. Kontribusi peradaban Islam Republik Yaman bagi dunia?

D. Jenis Penelitian

Peneliti dalam penulisan ini melakukan penelitian dengan menggunakan jenis penelitian kualitatif yakni dengan melakukan kajian kepustakaan dari berita-berita, jurnal-jurnal dan buku-buku yang yang terkait dengan tema penelitian.

E. Teknik Pengumpulan Data

Data penelitian penliti kumpulkan dengan menggunakan teknik dokumentasi yakni mencari tahu tentang data penelitian dari dokumen-dokumen yang berkaitan dengan materi atau data penelitian

F. Teknik Pengolahan dan Analisis Data 
Data penelitian diolah melalui diawali dengan prosedur pengumpulan data, kemudian melakukan reduksi data, selanjutnya data didisplay dan terakhir dengan vervikasi data. Langkah pengolahan dan analisis data melalui empat prosedur tersebut diharapkan dapat menghasilkan tulisan yang bermanfaat bagi siapa pun yang membacanya.

\section{G. Kajian Pustaka}

Penulis dalam kajian ini berusaha menelussri jurnal-jurnal atau hasil penelitian yang membahas tentang Kontribusi Republik Yaman dalam peradaban islam dunia tinjauan sejarah dakwah dan penulis hanya menemukan satu tulisan yang paling relevan dengan yang penulis bahas yakni jurnal dari Muhammad Fakhry Ghafur yang membahas tentang Problematika Kekuatan Politik Islam Di Yaman, Suriah, Dan Aljazair. Hasil penelitian mengungkapkan bahwa Gelombang revolusi atau yang lebih dikenal dengan Arab Spring yang melanda Timur Tengah dewasa ini telah mengubah peta politik di kawasan tersebut dengan munculnya kekuatan politik Islam, dalam arti aktivitas politik yang didasari oleh prinsipprinsip Islam baik dari titik tolak, program, agenda maupun tujuannya. Kendati demikian, di sejumlah negara masih saja ada sikap phobia terhadap Islam. Hal ini mengindikasikan adanya upaya pembalikan kembali ke rezim otoritarianisme atau "backward bending prosses" seperti yang terjadi di Tunisia, Mesir, dan Libya, dimana rezim militer dapat berkuasa kembali. Demikian juga di Yaman, rezim Ali Abdullah Saleh digantikan oleh wakilnya yang berhaluan militer, Abd Rabbuh Manshur Hadi, sampai akhirnya harus terusir oleh gerakan separatis Al-Houti. Sedangkan di Suriah kekuatan politik Islam kerap mendapat serangan dari rezim Bashar Al-Assad yang sampai saat ini masih berkuasa. Adapun di Aljazair meskipun tidak melebihi gejolak politik seperti yang terjadi di Yaman dan Suriahgerakan Islam yang terdiri dari Ikhwanul Muslimin dan kelompok Salafiyyah membentuk aliansi dan meraih suara signifikan dalam pemilu parlemen 2012 


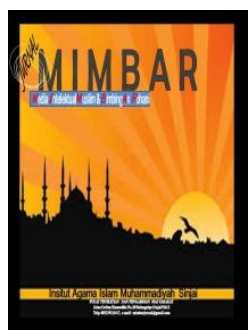

\section{MIMBAR}

Jurmal Media Intelektual Muslim dan Bimbingan Rohani

Volume 7, No. 1, 2021

ISSN (print) : 2442-3217

ISSN (online) : 2716-3806

Homepage : http://journal.iaimsinjai.ac.id/indeks.php/mimbar

meskipun pada akhirnya rezim militer dapat mendominasi kehidupan politik negara. 5

Tulisan di atas hanya sedikit memiliki kesamaan dengan yang penulis bahas tentang kondisi politik Republik Yaman yang menjadi salah satu bahasan dalam kajian penulis.

BAB II

\section{PEMBAHASAN}

\section{A. Masuknya Islam di Yaman}

Strategi dakwah yang dilakukan oleh Rasulullah saw dalam menyampaikan ajaran Islam beragam tergantung dari objek dakwahnya. Rasulullah saw juga diketahui berdakwah secara rahasia maupun secara terang-terangan, yang dimulai dari istrinya Khadijah, Ali bin Abi Thalib, Zaid bin Haritsah (pembantu rumah tangga kemudain diangkat menjadi anak), kemudian sahabatnya Abu Bakar Ash-Shiddiq, ajaran tersebut disampaikan secara berangsur-angsur hingga meluas. Namun pada waktu mula-mula berdakwah, Rasulullah saw masih berdakwah dilingkungan keluarga. ${ }^{6}$

\footnotetext{
${ }^{5}$ Muhammad Fakhry Ghafur yang membahas tentang PROBLEMATIKA KEKUATAN POLITIK ISLAM DI YAMAN, SURIAH, DAN ALJAZAIR, Jurnal Penelitian Politik | Volume 12 No. 2 Desember 2015

${ }^{6}$ Ni'matul Hasanah, Muhammad Yusuf, Pendidikan Pada Masa Rasulullah, https://doi.org/10.31219/osf.io/gc685
} 
Volume 7, No. 1, 2021

ISSN (print) : 2442-3217

ISSN (online) : 2716-3806

Homepage : http://journal.iaimsinjai.ac.id/indeks.php/mimbar

Berawal dari dakwah kepada keluarga kemudian ke masyarakat, dan ke berbagai negara di belahan dunia, Islam akhirnya menyebar luas ke seantero dunia. Perjalanan dakwah dari masa ke masa meskipun mengalami perkembangan yang dinamis, namun mengalami ragam rintangan sesuai dengan konteks dan zaman pada saat dakwah dilakukan. ${ }^{7}$

Berdasarkan beberapa sumber diketahui bahwa, Islam masuk ke Yaman bermula pada tahun $630 \mathrm{M}$. Nabi Muhammad SAW mengutus Ali bin Abi Thalib RA saudara sepupu sekaligus menantunya ke Sana'a dan sekitarnya untuk menyampaikan syiar Islam. Republik Yaman Pada waktu itu, merupakan wilayah yang paling maju di Semenanjung Arabia. Adapun yang tercatat sebagai kabilah yang pertama menerima Islam waktu itu adalah Bani Hamdan. ${ }^{8}$

Kedatangan Islam di Yaman terjadi pada masa pemerintahan Gubernur Persia Badhan . Yaman diperintah sebagai bagian dari kekhalifahan ArabIslam setelah itu dan menjadi salah sebuah provinsi yang berada dalam wilayah kerajaan Islam. ${ }^{9}$ Abad ke-11, Rezim yang berafiliasi dengan khalifah Fatimiyah Mesir menduduki sebagian besar Yaman utara dan

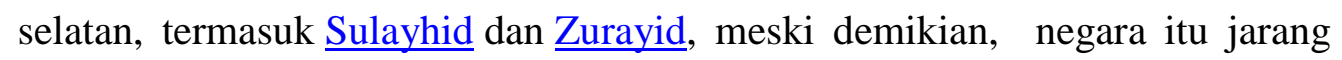
bersatu untuk jangka waktu yang lama. Kontrol lokal pada Abad Pertengahan dijalankan oleh keluarga yang berurutan yang meliputi Ziyadid (8181018), Najahid (1022-1158), Ayyubiyah Mesir (1174-1229)

dan Rasul Turki (1229-1454). Pemerintahan yang paling berumur panjang, dan untuk masa depan yang paling penting, didirikan pada tahun 897 oleh Yayha bin Husayn bin Qasim ar-Rassi. Mereka adalah Zaydis dari



\footnotetext{
${ }^{7}$ Faridah, Analisis Implementasi Keteladanan Dai dalam Efektivitas Dakwah di Era Kontemporer, Mimbar, Volume 1 Nomor 1, 2015, h.95., https://doi.org/10.47435/mimbar.v1i1.272

${ }^{8}$ Republika.Co.Id, Jakarta, Awal Masuknya Islam ke Yaman, Rabu 29 Mar 2017 diakses kamis 01 April 2021.

${ }^{9}$ https://en.wikipedia.org/wiki/Islamic_history_of_Yemen, diakses kamis 01 April 2021.
} 
Volume 7, No. 1, 2021

ISSN (print) : 2442-3217

ISSN (online) : 2716-3806

Homepage : http://journal.iaimsinjai.ac.id/indeks.php/mimbar

berbagai garis keturunan $\underline{\text { Sayyid }}$. Sebagai Imam yang berkuasa di Yaman, mereka mendirikan struktur politik teokratis Syiah yang bertahan dengan beberapa interval hingga tahun 1962. Pada abad ke-19 yakni periode setelah 1517, Yaman adalah bagian nominal dari Kekaisaran Ottoman, meskipun pada kedua kesempatan itu para Imam Zaydi memperebutkan kekuasaan Turki dan akhirnya mengusir mereka. ${ }^{10}$

\section{B. Terjadinya Konflik di Republik Yaman}

Pada masa Muhammad, tanah Yaman termasuk konfederasi suku

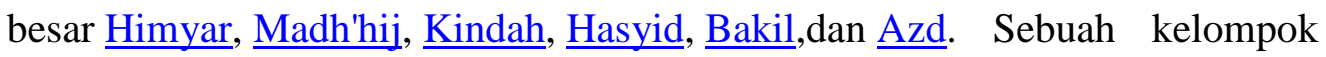

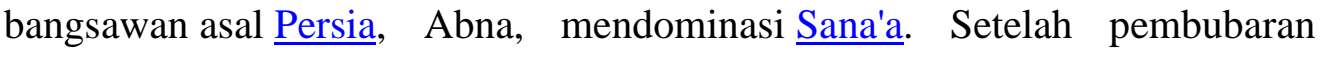
kekuasaan Persia di Arab Selatan, Abna beralih ke negara Islam yang sedang berkembang untuk mencari dukungan melawan pemberontak Arab setempat. Islamdiperkenalkan oleh fungsionaris Muhammad, tetapi tingkat pertobatannya tidak diketahui. Tanah itu tetap seperti di masa pra-Islam, dan agama baru menjadi faktor lain dalam konflik internal yang menimpa masyarakat Yaman sejak lama. Seorang al-Aswad al-Ansi memproklamasikan dirinya sebagai nabi pada tahun 632 dan mendapatkan dukungan di antara orang Yaman. Namun, dia dibunuh oleh Abna dan membelot dari anggota fraksinya sendiri di tahun yang sama. ${ }^{11}$

Rezim yang berafiliasi dengan khalifah Fatimiyah Mesir menduduki sebagian besar Yaman utara dan selatan sepanjang abad ke-11,

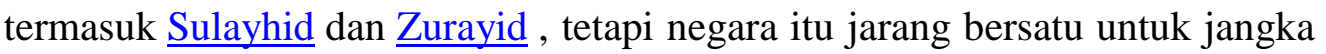
waktu yang lama. Kontrol lokal pada Abad Pertengahan dijalankan oleh keluarga yang berurutan yang meliputi Ziyadid (818-1018), Najahid (10221158), Ayyubiyah Mesir (1174-1229) dan Rasul Turki (1229-1454).

Pemerintahan yang paling berumur panjang, dan untuk masa depan yang

\footnotetext{
${ }^{10} \mathrm{https}: / /$ en.wikipedia.org/wiki/Islamic_history_of_Yemen, diakses kamis 01 April 2021

${ }^{11}$ Landau-Tasseron, Ella (2010). "Arab". Dalam Robinson,Chase F. (ed.). The New Cambridge History of Islam, Volume 1: The Formation of the Islamic World, Sixth to Eleventh Centuries. Cambridge: Cambridge University Press. hlm.415-416.
} 
Volume 7, No. 1, 2021

ISSN (print) : 2442-3217

ISSN (online) : 2716-3806

Homepage : http://journal.iaimsinjai.ac.id/indeks.php/mimbar

paling penting, didirikan pada tahun 897 oleh Yayha bin Husayn bin Qasim

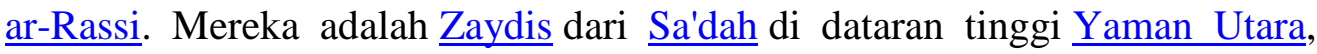
dipimpin oleh para imam dari

berbagai garis

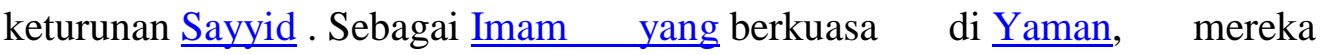
mendirikan struktur politik teokratis Syiah yang bertahan dengan beberapa interval hingga tahun $1962 .^{12}$

Pada tahun 660 M, Pasukan Muawiyah yakni pendiri Dinasti Umayyah, menaklukkan San'a dan Najran. Bani Umayyah memindahkan markas mereka ke luar Jazirah Arab, tetapi terus memberikan perhatian besar ke Yaman. Gubernur diangkat langsung oleh khalifah. Yaman secara administratif dikelompokkan bersama dengan Hijaz dan Yamama selama periode tertentu,. Namun, kendali efektif atas seluruh Yaman tidak tercapai. Tanah itu terancam oleh Khawarij dari Oman dan Bahrayn pada tahun 686689 M, pada tahun 692 kemudian diambil alih oleh Bani Umayyah cabang Marwanid. Terlepas dari pemerintahan yang sangat terdesentralisasi di tanah mereka, orang Yaman jarang memberontak melawan Bani Umayyah. Namun pada tahun 745-747 pemberontakan paling serius terjadi pada akhir dinasti yakni selama Fitnah Ketiga. Pemberontakan tersebut dipimpin oleh seorang suku Kindi bernama Abdallah bin Yahya, yang dikenal sebagai Thalib alHaqq. Dia memproklamasikan dirinya sebagai khalifah di Hadramawt, San'a, Mekah, dan Madinah . Ia berhasil dikalahkan pada tahun 747, namun akibatnya

kelompok Ibadiyyah di Hadramawt memperoleh hak yakni untuk sementara waktu memilih gubernur sendiri. ${ }^{13}$

Pada masa dinasti Abbasiyah, menurut sejarawan al-Yaqubi, Abbasiyah menggulingkan khalifah Umayyah dari semua tanah mereka

\footnotetext{
${ }^{12}$ https://en.wikipedia.org/wiki/Islamic_history_of_Yemen, diakses kamis 01 April 2021.

${ }^{13}$ Landau-Tasseron, Ella (2010). "Arab". Dalam Robinson, Chase F. (ed.). The New Cambridge History of Islam, Volume 1: The Formation of the Islamic World, Sixth to Eleventh Centuries . Cambridge: Cambridge University Press. hlm. 397-447. ISBN 978-0-521-83823-8.
} 
Volume 7, No. 1, 2021

ISSN (print) : 2442-3217

ISSN (online) : 2716-3806

Homepage : http://journal.iaimsinjai.ac.id/indeks.php/mimbar

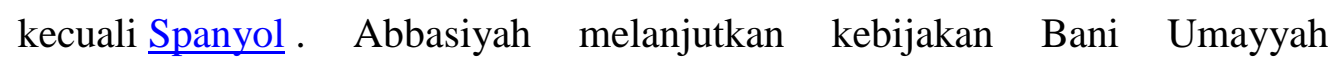
sehubungan dengan Yaman. Seringkali, seorang anggota aristokrasi Abbasiyah tertinggi termasuk pangeran dari dinasti, menjabat sebagai gubernur. Tapi Yaman tetap terfragmentasi. Saudara laki-laki dari Alid Ali arRidha yang terkenal, menduduki San'a dan dataran tinggi pada tahun 815 dan membuat koin atas namanya sendiri. Namun, dia segera dikalahkan oleh pasukan Khalifah al-Ma'mun . Namun demikian, setelah khalifah mencapai kesepakatan dengan Alids, Ibrahim ibn Musa yang sama diangkat menjadi gubernur Mekah dan Yaman. San'a tetap di bawah kendali khalifah untuk beberapa waktu. Namun, dalam perjalanan akhir abad ke-9, kekuatan Abbasiyah di berbagai daerah pinggiran menyusut. Dinasti lokal Yaman mulai bermunculan, entah menentang Abbasiyah atau mengakui mereka. ${ }^{14}$

Pada tahun 817 M, Khalifah al-Ma'mun menunjuk Umayyad Muhammad ibn Abdallah ibn Ziyad untuk memulihkan ketertiban di tanah Yaman yang bergolak. Ibn Ziyad mendirikan kekuasaannya di wilayah pesisir di barat ( Tihama ), dan mendirikan Zabid sebagai ibukotanya. Keluarga Ziyadid, sebutan keluarganya, mampu memperluas pengaruh mereka ke sebagian besar Yaman, termasuk Hadramawt dan setidaknya sebagian dataran tinggi. Selama itu mereka mengenali Abbasiyah dan menjalankan praktik-praktik keagamaan $\underline{\text { Sunni }}$. Namun, mereka harus bersaing dengan Yufirid yang mendominasi sebagian dataran tinggi setelah 847 M. Mereka akhirnya digulingkan oleh seorang menteri yang berkuasa pada tahun $1018 .{ }^{15}$

${ }^{14}$ Landau-Tasseron, Ella (2010). "Arab". Dalam Robinson, Chase F. (ed.). The New Cambridge History of Islam, Volume 1: The Formation of the Islamic World, Sixth to Eleventh Centuries. Cambridge: Cambridge University Press., hlm.419-421.

${ }^{15}$ Kay, Henry Cassels (1892). Yaman, Sejarah Awal Abad Pertengahan, oleh Najm ad-Dinn 'Omārah al-Hakami. Juga Ringkasan Sejarah Dinasti-Dinasti oleh Ibn Khaldūn, dan Catatan Karmathians Yaman oleh Abu 'Abd Allah Baha ad-Din al-Janadi . London: Edward Arnold., h. 1-18 
Volume 7, No. 1, 2021

ISSN (print) : 2442-3217

ISSN (online) : 2716-3806

Homepage : http://journal.iaimsinjai.ac.id/indeks.php/mimbar

Pada pertengahan abad ke-19, Ketertarikan Utsmaniyah di Yaman diperbarui. Salah satu tujuannya adalah untuk meningkatkan pengaruh Utsmaniyah dalam perdagangan Laut Merah, terutama sejak Inggris menduduki Aden sejak tahun 1839. Pembukaan Terusan Suezpada tahun 1869 meningkatkan insentif ini. Tihama diduduki pada tahun 1849, tetapi ekspedisi ke San'a gagal. Sementara itu, pada periode setelah 1849 terjadi serangkaian bentrokan yang membingungkan antara berbagai pihak yang mengklaim imamah di San'a dan Sa'dah. Kekacauan itu membuatnya jatuh berada di tangan Turki dan pada tahun 1872 sebuah ekspedisi baru mengamankan San'a dengan kerja sama beberapa penggugat Zaydi. Namun demikian, para pengklaim-imam terus menolak upaya Turki untuk memerintah Yaman, dan hanya sebagian dari negara itu yang dikendalikan secara efektif. Upaya modernisasi akhir Kekaisaran Ottoman menimbulkan ketidakpuasan di antara kalangan yang sangat tradisional, yang mencap kebijakan tersebut sebagai tidak Islami. ${ }^{16}$

Kesepakatan dengan imam pemberontak Imam Yahya Hamidaddin akhirnya tercapai pada tahun 1911, di mana yang terakhir diakui sebagai kepala Zaydis sementara Turki memungut pajak dari rakyat Sunni mereka. Sementara itu, kepentingan Turki dan Inggris bentrok di Yaman. Disepakati pada tahun 1902 untuk membatasi perbatasan antara bidang kepentingan masing-masing, dan sebuah perjanjian ditandatangani pada tahun 1914. Hal ini menjadi latar belakang bagi divisi selanjutnya di dua negara Yaman (hingga tahun 1990). Pada saat ini, Kekaisaran Ottoman hanya memiliki beberapa tahun tersisa. Pembubaran kekaisaran setelah Perang Dunia I menyebabkan penarikan total pada tahun $1918 .{ }^{17}$

\footnotetext{
${ }^{16}$ Caesar E. Farah, Sultan Yaman; Tantangan Abad Kesembilan Belas untuk PemerintahanOttoman. London: Tauris 2002.

${ }^{17}$ Dresch, Paul (2000). Sejarah Yaman Modern. Cambridge: Cambridge University Press., 47. Lihatjuga Encyclopedia of the modern Middle East and North Africa, Vol, IV, Detroit: ThomsonGale 2004, hal. 2390
} 
Setelah 1891, cabang Qasimid Hamid ad-Din mengklaim imamah tersebut. Pada awal abad ke-20 Imam Yahya mencetak keberhasilan yang signifikan melawan pasukan Turki, yang mengarah pada gencatan senjata tahun 1911. Selama Perang Dunia I Imam Yahya secara nominal menganut Ottoman, tetapi mampu mendirikan negara merdeka penuh pada tahun 1918. Itu dikenal sebagai Kerajaan Mutawakkilite setelah nama laqab Imam Yahya, al-Mutawakkil. Yahya menenangkan suku-suku Tihama dengan metode tangan besi. Dia juga tidak berhasil untuk memasukkan $\underline{\text { Asir }}$ dan Najran di wilayahnya (1934). Namun wilayah ini diakuisisi oleh Arab Saudi. Yaman Selatan tetap di bawah kendali Inggris sampai 1967 ketika menjadi negara merdeka. Yahya menikmati legitimasi di antara suku Zaydi di pedalaman, sementara penduduk Sunni di pesisir dan dataran tinggi selatan cenderung tidak menerima pemerintahannya. Untuk mempertahankan kekuasaan, dia bertindak sebagai raja turun-temurun dan menunjuk putranya sendiri untuk memerintah di berbagai provinsi. Rakyat yang tidak puas akhirnya membentuk Gerakan Yaman Merdeka, membunuh Imam Yahya pada tahun 1948 dengan tujuan untuk menciptakan monarki konstitusional. Namun, putranya Ahmad bin Yahya mampu mengambil alih kekuasaan dengan bantuan sekutu suku yang setia. Dia selanjutnya mempertahankan istananya di Ta'izz daripada San'a. ${ }^{18}$

Yaman menganut Republik Arab Bersatu yang diproklamasikan oleh presiden Mesir Nasser pada tahun 1958, bergabung dengan Mesir dan $\underline{\text { Suriah dalam koalisi longgar yang disebut Amerika Serikat Arab }}$. Namun, imam itu mundur ketika Suriah meninggalkan serikat pada tahun 1961. Militer pro-Mesir mulai berkomplot melawan penguasa. Ketika Ahmad bin Yahya meninggal pada tahun 1962, putranya Muhammad al-Badr dengan cepat digulingkan saat komplotan mengambil alih San'a. The Republik Arab

\footnotetext{
${ }^{18}$ Dresch 2000, A History of Modern Yemen., h. 43-57
} 
Volume 7, No. 1, 2021

ISSN (print) : 2442-3217

ISSN (online) : 2716-3806

Homepage : http://journal.iaimsinjai.ac.id/indeks.php/mimbar

Yaman diproklamasikan. Muhammad al-Badr berhasil melarikan diri ke loyalis di dataran tinggi, dan perang saudara menyusul. Arab Saudi mendukung imam itu sementara Mesir mengirim pasukan untuk menopang kaum republik. Setelah kekalahan Mesir melawan Israel pada tahun 1967, dan pembentukan republik rakyat sosialis di Yaman Selatan pada tahun yang sama, kedua kekuatan yang mengintervensi mencoba mencari solusi untuk membebaskan tangan mereka. Sebuah kesepakatan akhirnya tercapai pada tahun 1970 di mana kaum royalis setuju untuk menerima Republik Arab Yaman sebagai imbalan atas pengaruh dalam pemerintahan. ${ }^{19}$

Ottoman dibentuk kembali di Yaman utara pada abad ke-19 akhir tetapi kontrol sebagian besar terbatas pada kota-kota, dan aturan-aturan iman Zaidi atas Yaman secara resmi diakui. Pasukan Turki mundur pada tahun 1918, dan Imam Yahya Muhammad memperkuat kendalinya atas Yaman utara menciptakan Kerajaan Mutawakkilite Yaman. Yaman menjadi anggota Liga Arab pada 1945 dan PBB pada 1947. Namun, Imam Yahya meninggal dalam upaya kudeta yang gagal pada tahun 1948 kemudian digantikan oleh putranya Ahmad. Pemerintahan Ahmad bin Yahya ditandai dengan penindasan yang meningkat, gesekan baru dengan Inggris atas kehadiran Inggris di selatan dan meningkatnya tekanan untuk mendukung tujuan nasionalis Arab dari Presiden Mesir Gamal Abdul $\underline{\text { Nasser }} .^{20}$

Setelah mengambil alih kekuasaan pada tahun 1962, putra Ahmad yakni Putra Mahkota Muhammad al-Badr digulingkan oleh pasukan revolusioner yang mengambil kendali Sana'a dan menciptakan Republik Arab $\underline{\text { Yaman }}$ (YAR). Mesir membantu YAR dengan pasukan dan perbekalan untuk

${ }^{19}$ Commins, David (2010). "Arab Saudi, Arab selatan dan negara-negara Teluk dari Perang Dunia Pertama". Dalam Robinson, Francis (ed.). Sejarah Islam Cambridge Baru, Volume 5: Dunia Islam di Zaman Dominasi Barat. Cambridge: Cambridge University Press. 2010, h. 471473. ISBN 978-0-521-83826-9.

${ }^{20}$ https://en.wikipedia.org/wiki/Islamic_history_of_Yemen, diakses kami 01 April 2021. 
Homepage : http://journal.iaimsinjai.ac.id/indeks.php/mimbar

pasukan tempur yang setia kepada

Kerajaan. Arab

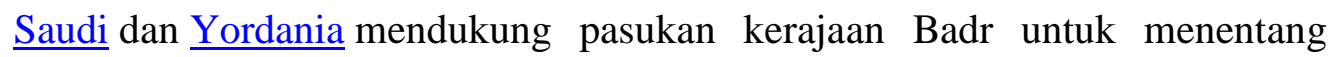
republik yang baru dibentuk yang memulai Perang Saudara Yaman Utara . Konflik berlanjut secara berkala hingga tahun 1967 ketika pasukan Mesir ditarik. Pada tahun 1968 setelah pengepungan terakhir oleh kaum royalis di Sana'a, sebagian besar pemimpin lawan mencapai rekonsiliasi dan Arab Saudi mengakui Republik tersebut pada tahun $1970 .^{21}$

Kepentingan Inggris di wilayah yang kemudian menjadi Yaman Selatan, mulai tumbuh ketika pada tahun 1839, pasukan British East India Company merebut pelabuhan $\underline{\text { Aden }, \quad \text { untuk }}$ menyediakan stasiun pemadaman batu bara untuk kapal-kapal yang sedang dalam perjalanan ke India. The koloni yang dikenal sebagai Settlement Aden, mendapatkan banyak politik dan strategis penting setelah pembukaan Terusan


India hingga 1937, ketika kota Aden menjadi Koloni Aden, sebuah koloni mahkota dengan sendirinya. Daerah pedalaman Aden dan Hadhramaut di timur membentuk sisa dari yang akan menjadi Yaman Selatan dan tidak dikelola secara langsung oleh Aden tetapi terikat dengan Inggris melalui perjanjian perlindungan. Dimulai pada dekade terakhir abad ke-19 dan berlanjut hingga abad ke-20, Inggris menandatangani perjanjian dengan penguasa lokal dari pemerintahan tradisional yang, bersama-sama, dikenal sebagai Protektorat Aden.. Daerah itu dibagi menjadi banyak kesultanan, emirat, dan kerajaan syekh, dan dibagi untuk tujuan administratif menjadi Protektorat Aden Timur dan Protektorat Aden Barat. Protektorat timur terdiri dari tiga negara Hadhramaut (Qu'aiti Negara Shihr dan Mukalla, Kathiri Negara Bagian Seiyun, Mahra

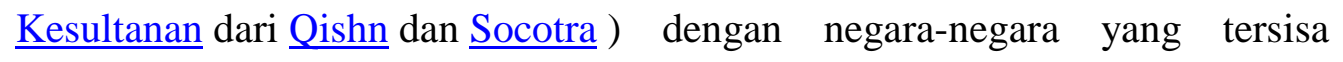

\footnotetext{
${ }^{21}$ https://en.wikipedia.org/wiki/Islamic history of Yemen, diakses kami 01 April 2021.
} 

ekonomi sebagian besar berpusat di Aden, dan sementara kota berkembang sebagian karena penemuan minyak mentah di Jazirah Arab.

Didorong oleh retorika Presiden Nasser dari Mesir untuk melawan pemerintahan kolonial Inggris di Timur Tengah, tekanan agar Inggris pergi mulai tumbuh. Menyusul pembentukan Republik Persatuan Arab oleh Nasser, upaya untuk memasukkan Yaman pada gilirannya mengancam Aden dan Protektorat. Untuk mengatasi hal ini, Inggris berusaha menyatukan berbagai negara di bawah perlindungannya dan, pada 11 Februari 1959, enam negara Protektorat Aden Barat membentuk Federasi Emirat Arab Selatan.yang kemudian ditambahkan sembilan negara bagian lainnya. Selama tahun 1960an, Inggris berusaha untuk memasukkan semua wilayah Protektorat Aden ke dalam Federasi. Pada tanggal 18 Januari 1963, Koloni Aden didirikan bertentangan dengan keinginan sebagian besar penduduk kota karena Negara Bagian Aden dan Federasi diubah namanya menjadi Federasi Arab Selatan . Beberapa negara bagian lain kemudian bergabung dengan Federasi dan negara bagian lainnya yang menolak untuk bergabung, terutama di Hadhramaut, membentuk Protektorat Arab Selatan .

Pada tahun 1963, pertempuran antara pasukan Mesir dan pimpinan British Saudi -financed gerilyawan di Yaman Republik Arab menyebar ke Arab Selatan dengan pembentukan Front Pembebasan Nasional (NLF), yang berharap untuk memaksa keluar Inggris dari Arab Selatan. Permusuhan dimulai dengan serangan granat oleh NLF terhadap Komisaris Tinggi Inggris pada 10 Desember 1963, menewaskan satu orang dan melukai lima puluh orang, dan keadaan darurat diumumkan, yang kemudian dikenal sebagai Darurat Aden. Pada tahun 1964, pemerintah Inggris yang baru di bawah Harold Wilson mengumumkan niat mereka untuk menyerahkan kekuasaan kepada Federasi Arab Selatan pada tahun 1968, tetapi militer Inggris akan tetap ada. Ada sekitar 280 serangan gerilya pada tahun 1964, dan 
lebih dari 500 pada tahun 1965. Pada tahun 1966, Pemerintah Inggris mengumumkan bahwa semua pasukan Inggris akan ditarik pada saat kemerdekaan. Sebagai tanggapan, situasi keamanan memburuk dengan pembentukan Front Sosialis untuk Pembebasan Yaman Selatan yang Diduduki (FLOSY) yang mulai menyerang NLF dalam upaya merebut kekuasaan, serta menyerang Inggris.

Pada bulan Januari 1967, terjadi kerusuhan massal oleh pendukung NLF dan FLOSY di kawasan Arab lama kota Aden, yang berlanjut hingga pertengahan Februari, meskipun ada intervensi dari pasukan Inggris. Selama periode tersebut terjadi banyak serangan terhadap pasukan, dan sebuah pesawat Aden Airways Douglas DC-3 hancur di udara tanpa ada yang selamat. Di saat yang sama, anggota FLOSY dan NLF juga saling membunuh dalam jumlah besar.

Penutupan sementara Terusan Suez pada tahun 1967 secara efektif meniadakan alasan terakhir bahwa Inggris mempertahankan koloni-koloni di Yaman, dan, dalam menghadapi kekerasan yang tak terkendali, mereka mulai menarik diri. Pada tanggal 20 Juni 1967, terjadi pemberontakan di Federasi Tentara Arab Selatan, yang juga menyebar ke polisi. Ketertiban dipulihkan oleh Inggris, terutama karena upaya Batalyon 1 Argyll dan Sutherland Highlanders , di bawah komando Letkol Colin Mitchell.

Inggris akhirnya menarik diri pada 30 November 1967, meninggalkan Aden di bawah kendali NLF. The Royal Marines, yang pernah menjadi tentara Inggris pertama yang menduduki Aden pada tahun 1839, adalah yang terakhir untuk meninggalkan. Federasi Arab Selatan runtuh, dan Yaman Selatan merdeka sebagai Republik Rakyat Yaman Selatan. NLF, dengan dukungan tentara, memperoleh kendali penuh atas negara baru setelah mengalahkan FLOSY dan negara bagian bekas Federasi dalam kampanye teror yang berlarut-larut. 
Volume 7, No. 1, 2021

ISSN (print) : 2442-3217

ISSN (online) : 2716-3806

Homepage : http://journal.iaimsinjai.ac.id/indeks.php/mimbar

Pada Juni 1969, sayap Marxis radikal dari NLF memperoleh kekuasaan dan mengubah nama negara menjadi Republik Demokratik Rakyat Yaman (PDRY) pada 1 Desember 1970. Di PDRY, semua partai politik digabung menjadi Partai Sosialis Yaman (YSP), yang menjadi satu-satunya pihak yang sah. PDRY menjalin hubungan dekat dengan Uni $\underline{\text { Soviet }}, \underline{\text { Republik Rakyat Cina }}, \underline{\text { Kuba }}$, dan orang-orang Palestina yang radikal. Kekuatan komunis utama ini membantu pembangunan angkatan bersenjata PDRY. Dukungan kuat dari Moskow mengakibatkan Angkatan

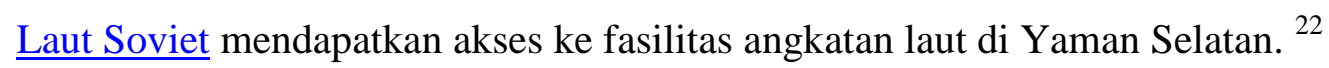

Meskipun pemerintah PDRY dan YAR menyatakan bahwa mereka menyetujui pekvrsatuan di masa depan pada tahun 1972, hanya sedikit kemajuan yang dicapai menuju unifikasi, dan hubungan sering tegang. Sebuah pernyataan dibuat pada tahun 1972 bahwa penyatuan pada akhirnya akan terjadi. Namun, pertempuran meletus antara Yaman Utara dan Yaman Selatan pada bulan Oktober tahun itu; Yaman Utara dipasok oleh Arab Saudi dan Yaman Selatan oleh Uni Soviet. Pertempuran itu berumur pendek, dan mengarah pada Perjanjian Kairo 28 Oktober 1972, yang mengedepankan rencana untuk menyatukan kedua negara. ${ }^{23}$

Pertempuran pecah lagi pada Februari dan Maret 1979, dengan Yaman Selatan diduga memasok bantuan kepada pemberontak di utara melalui Front Demokratik Nasional dan melintasi perbatasan. ${ }^{24}$ Pasukan Selatan berhasil mencapai kota Taizz sebelum mundur. ${ }^{25}$ Namun konflik ini berumur pendek. ${ }^{26}$ Perang ini berhasil dihentikan oleh intervensi Liga Arab dan tujuan

${ }^{22}$ https://en.wikipedia.org/wiki/Islamic history of Yemen, diakses kami 01 April 2021.

${ }^{23}$ Gause, Gregory, Saudi-Yemeni relations: domestic structures and foreign influence, Columbia University Press, 1990, page 98, lihat juga Studi CIA Tentang Unifikasi Yaman

${ }^{24}$ Hermann, Richard, Perceptions and behavior in Soviet foreign policy, University of Pittsburgh Pre, 1985, h.152

${ }^{25}$ Hoagland, Edward, Balancing Acts, Globe Pequot, 1999, h. 218.

${ }^{26}$ Burrowes, Robert, Middle East dilema: the politik dan ekonomi integrasi Arab, Columbia University Press, 1999, halaman 187 hingga 210. 
persatuan ditegaskan kembali oleh kepala negara utara dan selatan selama pertemuan puncak di Kuwait pada Maret 1979. Suatu hal yang gagal diberitahukan oleh pemerintah PDRY kepada pemerintah YAR adalah bahwa mereka ingin menjadi kekuatan dominan dalam penyatuan apa pun dan pemberontak sayap kiri di Yaman Utara mulai menerima dana dan senjata yang ekstensif dari Yaman Selatan. ${ }^{27}$

Presiden PDRY Abdul Fattah Ismail mengundurkan diri dan pergi ke pengasingan pada tahun 1980. Penggantinya, Ali Nasir

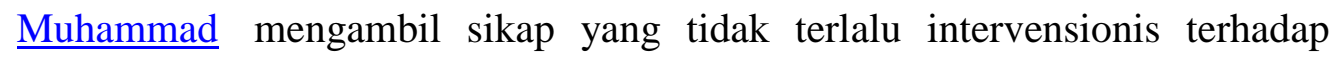
Yaman Utara dan negara tetangganya, Oman . Pada 13 Januari 1986 perang saudara pecah di Aden antara pendukung Ali Nasir dan pendukung Ismail yang kembali, mereka menginginkan kekuasaan kembali. Pertempuran berlangsung selama lebih dari sebulan dan menelan korban ribuan jiwa yakni sekitar 60.000 orang yang berujung pada penggulingan Ali Nasir dan kematian Ismail. Ali Nasir yang digulingkan, melarikan diri ke YAR. Pada bulan Mei 1988, pemerintah YAR dan PDRY mencapai kesepahaman yang sangat mengurangi ketegangan termasuk kesepakatan untuk memperbarui diskusi tentang penyatuan, untuk mendirikan wilayah eksplorasi minyak bersama di sepanjang perbatasan mereka yang tidak ditentukan, untuk mendemiliterisasi perbatasan, dan untuk mengizinkan lintas perbatasan yang tidak dibatasi Yaman dasar hanya kartu identitas nasional.

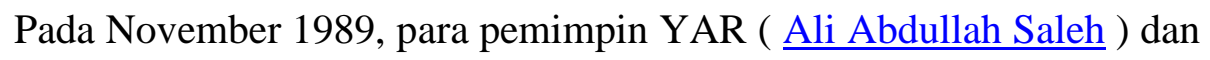

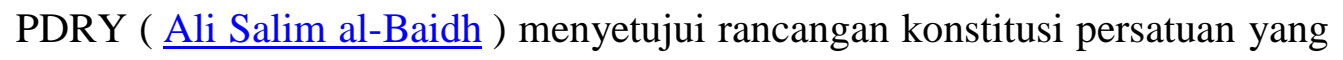
awalnya dibuat pada tahun 1981. Upaya penyatuan dimulai sejak 1988 dan pada 22 Mei 1990 kemerdekaan Republik Yaman dideklarasikan. ${ }^{28}$

The Republik Yaman (ROY) dideklarasikan pada tanggal 22 Mei 1990 dengan Saleh menjadi Presiden dan al-Baidh Wakil Presiden. Untuk pertama

${ }^{27}$ https://en.wikipedia.org/wiki/Islamic history of Yemen, diakses Kamis 1 April 2021

${ }^{28}$ https://en.wikipedia.org/wiki/Islamic_history_of_Yemen, diakses Kamis 1 April 2021 
kalinya dalam berabad-abad, sebagian besar wilayah geografis Yaman Raya bersatu secara politik. Konstitusi persatuan disepakati pada Mei 1990 dan diratifikasi oleh rakyat pada Mei 1991. Konstitusi tersebut menegaskan komitmen Yaman terhadap pemilihan umum yang bebas, sistem politik multipartai, hak untuk memiliki properti pribadi, kesetaraan di bawah hukum, dan penghormatan terhadap hak asasi manusia. Pemilihan parlemen diadakan pada tanggal 27 April 1993. Kelompok-kelompok internasional membantu penyelenggaraan pemilihan dan mengamati pemungutan suara yang sebenarnya. Parlemen yang dihasilkan termasuk 143 GPC, 69 YSP, 63 Islaah (pengelompokan Yaman untuk reformasi, sebuah partai yang terdiri dari berbagai kelompok suku dan agama), 6 Baathis, 3 Nasserist, 2 Al Haq, dan 15 independen. Ketua Parlemen, Paramount Hashid Sheik Abdallah Bin Husayn $\underline{\text { Al-Ahmar }}$, adalah ketua parlemen. Konflik dalam koalisi mengakibatkan pengasingan Wakil Presiden Ali Salim Al-Bidh ke Aden yang dilakukan sendiri mulai bulan Agustus 1993 dan memburuknya situasi keamanan secara umum ketika lawan politik menyelesaikan sejumlah masalah dan elemen suku mengambil keuntungan dari situasi yang tidak menentu. ${ }^{29}$

Mantan Perdana Menteri PDRY, Haydar Abu Bakar al-Attas, tetap menjabat sebagai Perdana Menteri ROY, tetapi pemerintahannya tidak efektif karena pertikaian politik. Negosiasi yang berkelanjutan antara para pemimpin utara dan selatan menghasilkan penandatanganan dokumen ikrar dan kesepakatan di Amman, Yordania pada 20 Februari 1994. Meskipun demikian, bentrokan semakin meningkat hingga pecah perang saudara pada awal Mei 1994. mengikuti tahap awal dari revolusi Tunisia dan terjadi bersamaan dengan Revolusi Mesir dan lainnya. massa protes di dunia Arab pada awal tahun 2011. Protes awalnya terhadap pengangguran, kondisi ekonomi dan korupsi, serta terhadap usulan pemerintah untuk

\footnotetext{
${ }^{29}$ https://en.wikipedia.org/wiki/Islamic_history_of_Yemen, diakses Kamis 1 April 2021
} 
mengubah konstitusi Yaman. Tuntutan para pemrotes kemudian meningkat menjadi seruan agar Presiden Ali Abdullah Saleh mengundurkan diri. ${ }^{30}$

Konflik di Yaman masih terus berlangsung pada hari Kamis (17/8/2017) Al Arabiya News Channel menyampaikan dalam beritanya bahwa Pasukan Perlawanan Populer di Yaman telah merebut kembali daerah-daerah kunci di sekitar basis Khalid Ibn al-Walid yang strategis di dekat pantai barat negara tersebut,.$^{31}$

Krisis Yaman telah menjadi konflik yang menyebabkan banyak korban, perusakan, kekerasan, dan anarki. PBB menjuluki krisis Yaman sebagai "krisis kemanusiaan terburuk". Intervensi dari berbagai negara telah menyebabkan kecurigaan terhadap agenda tersembunyi pada konflik. Dari sudut pandang geopolitik, konflik ini strategis bagi kepentingan negara-negara yang terlibat, sehingga memperlama jalannya konflik dan mempersulit tercapainya sebuah resolusi bagi Perang Saudara Yaman. ${ }^{32}$

Berbagai literatur di atas menguraikan bahwa konflik di Republik Yaman di sebabakan oleh berbagai faktor dan kepentingan termasuk ekonomi, sosial, agama dan politik.

\section{Kontribusi Peradaban Islam Republik Yaman Bagi Dunia}

Negara yang memiliki beberapa pulau terpisah ini memiliki kekayaan sejarah peradaban kuno sejak ribuan tahun lalu.Dalam catatan sejarah, Yaman menjadi bagian pusat perdagangan antara India, Cina, Afrika, dan Mediterania. ${ }^{33}$

Sejak awal, Yaman berada di garis depan pasukan Islam yang berkembang dan dipercayakan sejumlah tugas penting. Selama partisipasi

\footnotetext{
${ }^{30} \mathrm{https} / / /$ en.wikipedia.org/wiki/Islamic_history_of_Yemen, diakses Kamis 1 April 2021

${ }^{31}$ Https://Jurnalislam.Com/12-000-Pasukan-Di-Pantai-Barat-Yaman-Rebut-Kembali-TaizDan-Hudaydah-Dari-Syiah-Houthi, Diakses Jum'at 2 April 2021.

${ }^{32}$ Alvis Rahman Bhasuki Dkk, Perang Saudara Di Yaman: Analisis Kepentingan Negara Interventif Dan Prospek Resolusi Konflik, Jurnal Ilmu Politik Dan Komunikasi, Vol IX, No.1. 2019.

${ }^{33} \mathrm{Https} / / /$ Www.Republika.Co.Id/Berita/Pcrk18313/Yaman-Negara-Tua-Kaya-Peradaban-1, Diakses Kamis 1 April 2021.
} 


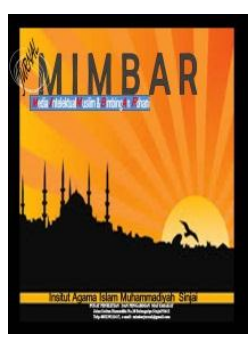

\section{MIMBAR}

Jurmal Media Intelektual Muslim dan Bimbingan Rohani

Volume 7, No. 1, 2021

ISSN (print) : 2442-3217

ISSN (online) : 2716-3806

Homepage : http://journal.iaimsinjai.ac.id/indeks.php/mimbar

mereka dalam tentara Islam, Yaman mentransfer banyak pengetahuan. Mereka dengan jelas dan jelas berpartisipasi dalam mendirikan kota dan membangun benteng, serta pembangunan istana dan keterampilan lainnya. Keterlibatan Yaman dalam perjalanan peristiwa tidak berhenti selama Kekhalifahan. ${ }^{34}$

Kontribusi Yaman terhadap pencapaian peradaban gemilang umat muslim abad pertengahan sangat besar.banyak dari penduduk yang terjun di kancah kemiliteran kekhalifahan. Penduduk Yaman turut serta dalam ekspedisi perluasan wilayah Islam yang berakhir sukses. ${ }^{35}$

Berdasarkan uraian tersebut di atas, maka dapat diketahui dan dipahami bahwa negara Republik Yaman memberikan kontribusi yang sangat besar terhadap peradaban Islam dunia seperti penyebaran ilmu pengetahuan dan partisipasi dalam perluasan wilayah Islam.

${ }^{34}$ Https://En.Wikipedia.Org/Wiki/Islamic_History_Of_Yemen, Diakses Kamis 01 April 2021

${ }^{35} \mathrm{Https} / / /$ Www.Republika.Co.Id/Berita/Pcrk18313/Yaman-Negara-Tua-Kaya-Peradaban-1, DIAKSES Kamis 1 April 2021. 


\section{BAB III PENUTUP}

\section{A. KESIMPULAN}

Sejarah kedatangan Islam di Republik Yaman menceritakan tentang masuknya Islam di Yaman sejak masa Rasulullah saw yang mengutus sepupu sekaligus menantunya Ali bin Abi Thalib untuk berdakwah di Yaman

Republik Yaman diwarnai oleh konflik yang berkepanjangan, berawal dari krisis yang menjadi konflik dan menyebabkan banyak korban, perusakan, kekerasan, dan anarki. PBB menjuluki krisis Yaman sebagai "krisis kemanusiaan terburuk". Intervensi dari berbagai negara telah menyebabkan kecurigaan terhadap agenda tersembunyi pada konflik. Dari sudut pandang geopolitik, konflik ini strategis bagi kepentingan negara-negara yang terlibat, sehingga memperlama jalannya konflik dan mempersulit tercapainya sebuah resolusi bagi Perang Saudara Yaman. Ada berbagai faktor dan kepentingan termasuk ekonomi, sosial, agama dan politik yang menjadi penyebab konflik di Yaman.

Kontribusi peradaban Islam Republik Yaman bagi dunia cukup besar, adanya transfer ilmu pengetahuan dan keikutsertaan penduduk Yaman dalam ekspedisi perluasan wilayah Islam merupakan salah satu contoh konkritnya.

B. SARAN

Kajian tentang perkembangan Islam di beberapa negara masih sangat kurang, padahal materi tentang hal ini juga penting menjadi kajian untuk langkah-langkah perkembangan dan kemajuan Islam di masa depan. Sehingga sangat diharapkan kreatifitas dari akademisi untuk memperbanyak kajian atau tulisan termasuk dalam kajian sejarah untuk jadi pembelajaran. 


\section{DAFTAR PUSTAKA}

Alvis Rahman Bhasuki Dkk, Perang Saudara Di Yaman: Analisis Kepentingan Negara Interventif Dan Prospek Resolusi Konflik, Jurnal Ilmu Politik Dan Komunikasi, Vol IX, No.1.2019.

Burrowes, Robert, Middle East dilema: the politik dan ekonomi integrasi Arab, Columbia University Press, 1999, halaman 187 hingga 210

Commins, David (2010). "Arab Saudi, Arab selatan dan negara-negara Teluk dari Perang Dunia Pertama". Dalam Robinson, Francis (ed.). Sejarah Islam Cambridge Baru, Volume 5: Dunia Islam di Zaman Dominasi Barat. Cambridge: Cambridge University Press. 2010, h. 471473. ISBN 978-0-521-83826-9.

Dresch 2000, A History of Modern Yemen., h. 43-57

Faridah, Analisis Implementasi Keteladanan Dai dalam Efektivitas Dakwah di Era

Kontemporer, Mimbar, Volume 1 Nomor 1, 2015,

h.95., https://doi.org/10.47435/mimbar.v1i1.272

Gause, Gregory, Saudi-Yemeni relations: domestic structures and foreign influence, Columbia University Press, 1990, page 98, lihat juga Studi CIA Tentang Unifikasi Yaman

Https://En.Wikipedia.Org/Wiki/Islamic_History_Of_Yemen, Diakses Kamis 01 April 2021

Https://Www.Republika.Co.Id/Berita/Pcrk18313/Yaman-Negara-Tua-Kaya-

Peradaban-1, DIAKSES Kamis 1 April 2021.

https://en.wikipedia.org/wiki/Islamic_history_of_Yemen, diakses Kamis 1 April 2021

https://en.wikipedia.org/wiki/Islamic_history_of_Yemen, diakses Kamis 1 April 2021

Https://Jurnalislam.Com/12-000-Pasukan-Di-Pantai-Barat-Yaman-Rebut-Kembali-

Taiz-Dan-Hudaydah-Dari-Syiah-Houthi, Diakses Jum'at 2 April 2021.

Https://Www.Republika.Co.Id/Berita/Pcrk18313/Yaman-Negara-Tua-Kaya-

Peradaban-1, Diakses Kamis 1 April 2021. 


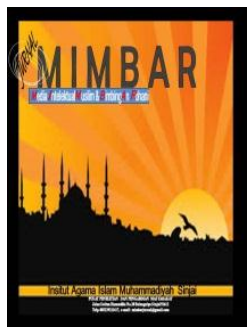

\section{MIMBAR}

Jurmal Media Intelektual Muslim dan Bimbingan Rohani

Volume 7, No. 1, 2021

ISSN (print) : 2442-3217

ISSN (online) : 2716-3806

Homepage : http://journal.iaimsinjai.ac.id/indeks.php/mimbar

https://en.wikipedia.org/wiki/Islamic_history_of_Yemen, diakses kami 01 April 2021.

Hermann, Richard, Perceptions and behavior in Soviet foreign policy, University of Pittsburgh Pre, 1985, h.152

Hoagland, Edward, Balancing Acts,Globe Pequot, 1999, h. 218.

https://en.wikipedia.org/wiki/Islamic_history_of_Yemen, diakses kami 01 April 2021.

Kay, Henry Cassels (1892). Yaman, Sejarah Awal Abad Pertengahan, oleh Najm adDìn 'Omārah al-Hakami. Juga Ringkasan Sejarah Dinasti-Dinasti oleh Ibn Khaldūn, dan Catatan Karmathians Yaman oleh Abu 'Abd Allah Baha ad-Din al-Janadi . London: Edward Arnold., h. 1-18.

Landau-Tasseron, Ella (2010). "Arab". Dalam Robinson, Chase F. (ed.). The New Cambridge History of Islam, Volume 1: The Formation of the Islamic World, Sixth to Eleventh Centuries. Cambridge: Cambridge University Press. hlm. 397-447. ISBN 978-0-521-83823-8.

Landau-Tasseron, Ella (2010). "Arab". Dalam Robinson, Chase F. (ed.). The New Cambridge History of Islam, Volume 1: The Formation of the Islamic World, Sixth to Eleventh Centuries. Cambridge: Cambridge University Press., hlm.419-421.

Nourouzzaman Shiddiqie, Pengantar Sejarah Muslim (Yogyakarta: Nur Cahaya, 1983), h.65.

http://www.geografi.org/2017/04, diakses Jum'at 02 April 2021.

Ni'matul Hasanah, Muhammad Yusuf, Pendidikan Pada Masa Rasulullah, https://doi.org/10.31219/osf.io/gc685

Samsul Munir Amin, Sejarah Peradaban Islam(Cet. II; Jakarta: Sinar Grafika Offset, 2010), h. 3 